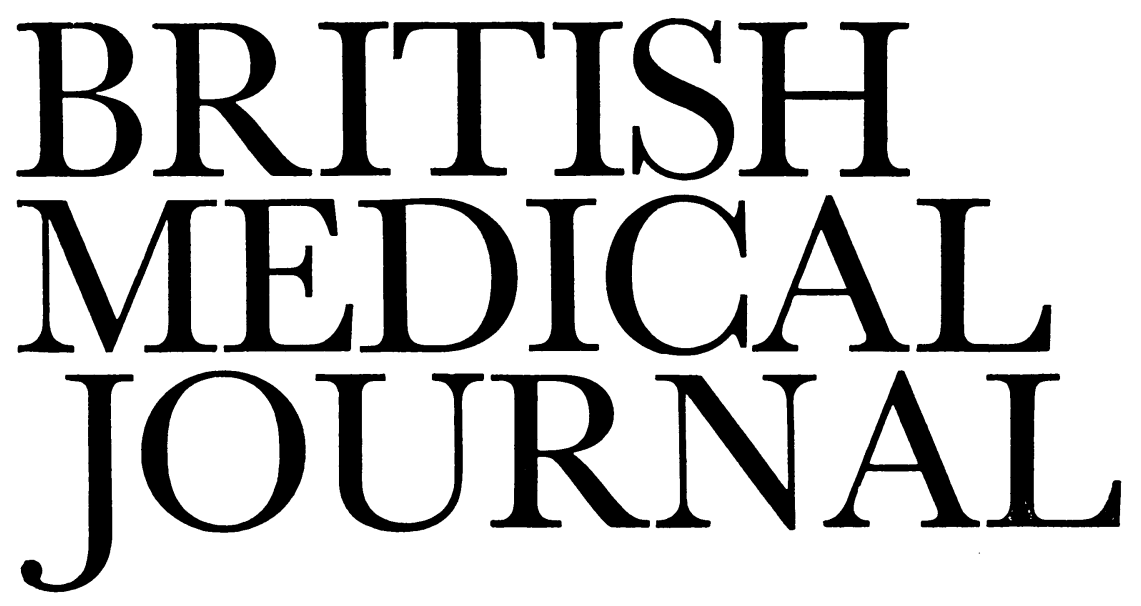

LONDON, SATURDAY 28 JANUARY 1984

\title{
Opioid peptides
}

Evidence of the intensity of recent research on the pharmacology of opioids is provided by the publication of the British Medical Bulletin on "Opioid peptides"1 and the recent symposium on "Opioids, past, present and future" held at Cambridge to celebrate the 80th birthday of Professor Hans Kosterlitz, FRS. It is barely 10 years since opiate binding sites were first shown in the brain and gut, ${ }^{2-4}$ and an endogenous ligand was found in the brain which later turned out to be two closely related pentapeptides subsequently named [met]enkephalin and [leu]enkephalin. ${ }^{5}$ Since then the number of peptides and their receptors has multiplied, and it has become necessary to invent new terms and to redefine old ones. "Opiate" refers specifically to the products derived from the juice of the opium poppy (although it has been loosely applied to morphine derivatives), while the term "opioid" refers to any directly acting compound whose effects are stereospecifically antagonised by naloxone. Peptides with this property are now known as "opioid peptides."6 7

There are at least five groups of naturally occurring opioid peptides $^{8}$ : [met]enkephalin and [leu]enkephalin; peptides that arise (or are presumed to arise) from enkephalin precursors and which include dynorphin, ${ }^{9}$ peptide $E,{ }^{10} \alpha-$ neoendorphin and $\beta$-neoendorphin ${ }^{11}$ and $\mathrm{PH}-8 \mathrm{P},{ }^{12}$ and two other peptides, [met]enkephalin-arginine-phenylalanine and [met] enkephalin-arginine-glycine-leucine; $\beta$-endorphin ${ }^{1314}$ and the related $\alpha-, \gamma-$, and $\delta$-endorphins ${ }^{15}$; pronase resistant peptides which are present in body fluids-for example, $\beta$-casomorphin-5 and -7 in bovine milk ${ }^{16}$; and various other peptides which act indirectly.

Those opioid peptides and their associated receptors which seem to be concerned in physiological, pathophysiological, and pharmacological mechanisms have attracted most interest. These comprise three families of opioid peptides and their associated neurones-the enkephalins, dynorphins, and endorphins. Each is derived by enzyme cleavage from a larger and independent precursor-proenkephalin A, proenkephalin B (prodynorphin), and pro-opiomelanocortin, respectively (the latter is also the precursor of corticotrophin and $\beta$-lipotropin). The opioid peptides may function as short acting neurotransmitters or as long acting neurohormones, and many show overlapping effects in their receptor mediated actions. This is not surprising in view of their similarity in structure. The three precursors appear to account for all of the known endogenous opioid peptides, ${ }^{17}$ and they are syn- thesised under the direction of messenger ribonucleic acid on membrane bound polyribosomes. They have molecular weights of 28-32 kilodaltons and contain repeated biologically active sequences. ${ }^{17}$

There are at least three distinct, but possibly interconvertible, opioid receptors ${ }^{18-20}$ - designated $\mathrm{mu}(\mu)$, Kappa $(\kappa)$, and delta $(\delta)^{21}$-which are closely related to the opioid peptides. ${ }^{6}$ The enkephalins contain short neurones which are distributed widely, but are most prominent in the striatum (especially the globus pallidus), the preoptic area of the hypothalamus, the limbic system, raphe nuclei, spinal cord, adrenal medulla, sympathetic ganglia, and the myenteric plexus of the gastrointestinal tract. The opioid peptides which are stored with catecholamines in chromaffin tissue are the pentapeptides [met]enkephalin and [leu]enkephalin, and these are short acting agonists or neurotransmitters at $\mu$ and $\delta$ receptors, respectively. The dynorphin family contains neurones which are probably widespread, reaching their highest concentration in the posterior pituitary, hypothalamus, and submucous plexus of the gastrointestinal tract. The complete heptadecapeptide form of dynorphin (dynorphin ${ }_{1-17}$ ) is a long acting agonist or modulator at $\kappa$ receptors, while the shorter forms $\left(\right.$ dynorphin $_{1-8}$ or dynorphin $_{1-9}$ ) are short acting agonists at $\kappa$ receptors. Owing to their close chemical similarities dynorphin and $\beta$-neoendorphin are also long acting agonists at $\mu$ and $\delta$ receptors. The endorphin family contains discretely distributed neurones associated with the anterior lobe of the pituitary and hypothalamus, and $\beta$-endorphin is a long acting agonist at $\mu$ and $\delta$ receptors. Thus neurotransmission is carried out by the shorter length opioid peptides of the enkephalin and dynorphin families, whereas neuronal or hormonal modulation is carried out by the longer length peptides of all three families-namely, peptide $\mathrm{E}(\mu, \delta)$, dynorphin $(\mu, \kappa), \beta$-neoendorphin $(\delta, \kappa)$, and $\beta$-endorphin $(\mu, \delta)$.

From the results of recent experiments the role of opioid peptides in physiological and pathophysiological processes is beginning to emerge. In general terms the opioid peptides form the chemical messengers (neurotransmitters, hormones, or neurohormones) of a widespread and complex inhibitory signalling system in which the selectivity of a messenger is achieved by the use of a combination of specific opioid peptides and receptors. At a cellular level it seems likely that this is achieved by membrane hyperpolarisation due to 
opening of potassium channels ${ }^{22} 23$ or by a depression of transmitter release. ${ }^{24-29}$ Even though opioid peptides appear to have an excitatory effect in the ganglion cells of the retina, ${ }^{30}$ the output neurones (mitral cells) of the olfactory bulb, ${ }^{31}$ and the pyramidal cells of the hippocampus, ${ }^{32}{ }^{33}$ the evidence is that all these actions are due to disinhibition of tonically active adjacent inhibitory interneurones. ${ }^{33} 34$

In man opioid peptides are found mainly in the sensory and autonomic systems, limbic structures, and neuroendocrine systems, ${ }^{35}$ where they operate as part of a widespread inhibitory system. This system is largely quiescent under physiological conditions and becomes active only during pathophysiological states. Thus opioid inhibition of pain is not tonic but needs a pre-existing noxious stimulus to activate the system. ${ }^{36}{ }^{37}$ This helps to explain the mechanism of action of transcutaneous nerve stimulation, acupuncture, and also the absence of hyperalgesia after naloxone has been given to a person who is not in pain. ${ }^{38}$ Furthermore, synthetic opioid peptides such as $\beta$-lipotropin ${ }_{66-91}$ may inhibit $\beta$-endorphin induced analgesia, suggesting that endogenous peptides may exist in the central nervous system to regulate further the actions of endorphin. ${ }^{39}$ Autonomic reflexes concerned with normal respiratory and cardiovascular control in man do not appear to involve opioid peptides, whereas under conditions of stress-for example, anaesthesia, surgery, pain, hypoxia, shock, the neonatal state, and so on-opioid peptides are concerned, ${ }^{40}$ so that the development of selective antagonists has great therapeutic potential. ${ }^{41}$ This has already been illustrated by the successful use of naloxone in septic shock. ${ }^{42}{ }_{43}$ The prominent effect of opiates on mood and behaviour is thought to be due to actions on the limbic and extrapyramidal systems. There is evidence of both $\delta$ and $\mu$ receptors in the striatum, while the limbic system contains predominantly $\delta$ receptors, but their physiological role is not yet understood..$^{35}$ There is no firm evidence that psychopathological states such as schizophrenia and affective psychoses are primarily the result of disrupted opioid systems. In the neuroendocrine system opioid peptides impose tonic inhibitory control over corticotrophin and gonadotrophins via the inhibition of corticotrophin releasing factor and luteinising hormone releasing hormone, respectively, although in conditions of stress opioid peptides are probably concerned in the release of corticotrophin releasing factor. Opioid peptides stimulate release of prolactin, growth hormone, and thyroid stimulating hormone, probably via $\beta$-endorphin acting on $\mu$ receptors, but this is probably not of great physiological importance. By contrast, vasopressin and oxytocin are under predominantly inhibitory control probably via [leu]enkephalin or dynorphin acting via $\delta$ or $\kappa$ receptors. ${ }^{44}$

What is abundantly clear is that we are still only at the beginning of the opioid story. The need to develop highly specific agonists and antagonists with which to probe and ultimately to control the opioid network is all too apparent. But the future is exciting and full of promise and the therapeutic rewards are likely to be great.

JOHN W THOMPSON

Professor of Pharmacology,

University of Newcastle upon Tyne, and

Consultant Clinical Pharmacologist,

Pain Relief Clinic,

Royal Victoria Infirmary,

Newcastle upon Tyne NE1 4LP

${ }^{1}$ Hughes J, ed. Opioid peptides. Br Med Bull 1983;39:1-106.

2 Pert CB, Snyder SH. Opiate receptor: demonstration in nervous tissue. Science 1973;179:1011-4.

${ }^{3}$ Simon EJ, Hiller JM, Edelman I. Stereospecific binding of the potent narcotic analgesic $(3 \mathrm{H})$ etorphine to rat-brain homogenate. Proc Natl Acad Sci USA 1973;70:1947-9.

${ }^{4}$ Terenius L. Stereospecific interaction between narcotic analgesics and a synaptic plasma membrane fraction of rat cerebral cortex. Acta Pharmacol Toxicol 1973;32:317-20.

${ }^{5}$ Hughes J, Smith TW, Kosterlitz HW, Fothergill IA, Morgan B, Morris HR. Identification of two related pentapeptides from the brain with potent opiate agonist activity. Nature 1975;258:577-9.

${ }^{6}$ Hughes J, Kosterlitz HW. Introduction. Br Med Bull 1983;39:1-3.

${ }^{7}$ Anonymous. Opiates or opioids. Lancet 1983;i:687.

${ }^{8}$ Morley JS. Chemistry of opioid peptides. Br Med Bull 1983;39:5-10.

${ }^{9}$ Goldstein A, Fischli W, Lowney LI, Hunkapiller M, Hood L. Porcine pituitary dynorphin: complete amino acid sequence of the biologically active heptadecapeptide. Proc Natl Acad Sci USA 1981;78:7219-23.

${ }^{10}$ Kilpatrick DL, Taniguchi T, Jones BN, et al. A highly potent 3200-dalton adrenal opioid peptide that contains both a (met)- and (leu)enkephalin sequence. Proc Natl Acad Sci USA 1981;78:3265-8.

${ }^{11}$ Kangawa K, Minamino N, Chino N, Sakakibara S, Matsuo $H$. The complete amino acid sequence of alpha-neo-endorphin. Biochem Biophys Res Commun 1981;99:871-8.

${ }^{12}$ Minamino N, Mizuna K, Hayashi Y, et al. Endogenous "big" leuenkephalins from porcine hypothalamus: purifications, structures and syntheses of $a-, \quad \beta$-neo-endorphin and PH-8P. In: Okawa K, ed. Peptide chemistry. Osaka: Protein Research Foundation, 1980:145-50.

${ }^{13}$ Bradbury AF, Smyth DG, Snell CR, Birdsall NJM, Hulme EC. C fragment of lipotropin has a high affinity for brain opiate receptors. Nature $1976 ; 260: 793-5$.

${ }^{14} \mathrm{Li} \mathrm{CH}$, Chung D. Isolation and structure of an untriakontapeptide with opiate activity from camel pituitary glands. Proc Natl Acad Sci USA $1976 ; 73: 1145-8$.

${ }^{15}$ Ling N, Burgus R, Guillemin R. Isolation, primary structure, and synthesis of alpha-endorphin and gamma-endorphin, two peptides of hypothalamic-hypophyseal origin with morphinomimetic activity. Proc Natl Acad Sci USA 1976;73:3942-6.

${ }^{16}$ Henschen A, Lottspeich F, Brantl V, Teschemacher H. Novel opioid peptides derived from casein (beta-casomorphins). II. Structure of active components from bovine casein peptone. Hoppe Seylers $Z$ Physiol Chem 1979;360:1217-24.

${ }^{17}$ Hughes J. Biogenesis, release and inactivation of enkephalins and dynorphins. Br Med Bull 1983;39:17-24.

${ }^{18}$ Bowen WD, Gentleman S, Herkenham M, Pert CB. Interconverting mu and delta forms of the opiate receptor in rat striatal patches. Proc Natl Acad Sci USA 1981 ;78:4818-22.

${ }^{19}$ Pasternak GW. High and low affinity opioid binding sites: relationship to mu and delta sites. Life Sci 1982;31:1303-6.

${ }^{20}$ Barnard EA, Demoliou-Mason C. Molecular properties of opioid receptors. Br Med Bull 1983;39:37-45.

${ }^{21}$ Paterson SJ, Robson LE, Kosterlitz HW. Classification of opioid receptors. Br Med Bull 1983;39:31-6.

22 Wouters W, Van den Bercken J. Effects of met-enkephalin on slow synaptic inhibition in frog sympathetic ganglion. Neuropharmacology 1980;19: 237-43.

${ }^{23}$ Wouters W, Van den Bercken J. Hyperpolarisation and depression of slow synaptic inhibition by enkephalin in frog sympathetic ganglion. Nature 1979;277:53-4.

${ }^{24}$ Schaumann $\mathbb{W}$. Influence of atropine and morphine on the liberation of acetylcholine from the guinea pig's intestine. Nature 1956;178:1121-2.

${ }^{25}$ Paton WDM. The action of morphine and related substances on contraction and on acetylcholine output of coaxially stimulated guinea-pig ileum. British fournal of Pharmacology and Chemotherapy 1957;12: 119-27.

${ }^{26}$ Kosterlitz HW, Watt AJ. Kinetic parameters of narcotic agonists and antagonists, with particular reference to $\mathrm{N}$-allylnoroxymorphone (naloxone). British fournal of Pharmacology and Chemotherapy 1968;33: 266-76.

${ }^{27}$ North RA, Tonini M. The mechanism of action of narcotic analgesics in the guinea-pig ileum. Br f Pharmacol 1977;61:541-9.

${ }^{28}$ Morita K, North RA. Opiates and enkephalin reduce the excitability of neuronal processes. Neuroscience $1981 ; 6: 1943-51$.

${ }^{29}$ Henderson G. Electrophysiological analysis of opioid action in the central nervous system. Br Med Bull 1983;39:59-64.

${ }^{30}$ Djamgoz MBA, Stell WK, Chin C-A, Lam DMK. An opiate system in the goldfish retina. Nature $1981 ; 292: 620-3$.

${ }^{31}$ Nicoll RA, Alger BE, Jahr CE. Enkephalin blocks inhibitory pathways in the invertebrate CNS. Nature 1980;287:22-5.

${ }^{32}$ Nicoll RA, Siggins GR, Ling N, Bloom FE, Guillemin R. Neuronal actions of endorphins and enkephalins among brain regions: a comparative microiontophoretic study. Proc Natl Acad Sci USA 1977;74: 2584-8.

${ }^{33}$ Zieglgänsberger W, French ED, Siggins GR, Bloom FE. Opioid peptides may excite hippocampal pyramidal neurons by inhibiting adjacent inhibitory interneurons. Science $1979 ; \mathbf{2 0 5}: 415-7$.

${ }^{34}$ Duggan AW. Electrophysiology of opioid peptides and sensory systems. Br Med Bull 1983;39:65-70.

${ }^{35}$ Atweh SF, Kuhar MJ. Distribution and physiological significance of opioid receptors in the brain. Br Med Bull 1983;39:47-52.

${ }^{36} \mathrm{Koob}$ GF, Bloom FE. Behavioural effects of opioid peptides. $\mathrm{Br} \mathrm{Med}$ Bull 1983;39:89-94.

37 Watkins LR, Mayer DJ. Organization of endogenous opiate and nonopiate pain control systems. Science 1982;216:1185-92. 
${ }^{38}$ Buchsbaum MS, Davis GC, Bunney WE Jr. Naloxone alters pain perception and somatosensory evoked potentials in normal subjects. Nature $1977 ; \mathbf{2 7 0}: 620-2$.

${ }^{39}$ Lee NM, Friedman HJ, Leybin L, Cho TM, Loh HH, Li CH. Peptide inhibitor of morphine- and beta-endorphin-induced analgesia. Proc Natl Acad Sci USA 1980;77:5525-6.

${ }^{40}$ McQueen DS. Opioid peptide interactions with respiratory and circulatory systems. Br Med Bull 1983;39:77-82.

${ }^{41}$ Clement-Jones V, Besser GM. Clinical perspectives in opioid peptides. Br Med Bull 1983;39:95-100.

42 Peters WP, Johnson MW, Friedman PA, Mitch WE. Pressor effect of naloxone in septic shock. Lancet $1981 ; \mathrm{i}: 529-32$.

${ }^{43}$ Anonymous. Naloxone for septic shock. Lancet 1981 ; i :538-9.

${ }^{44}$ Grossman A, Rees LH. The neuroendocrinology of opioid peptides. $\mathrm{Br}$ Med Bull 1983;39:83-8.

\section{Drugs and insomnia}

Insomnia occurs in so many circumstances that it is often difficult to know when a hypnotic should be used and which is most suitable. In the past 10 years or so considerable advances have been made, however, in understanding sleep and sleep disturbance, and many more drugs, both diazepines and non-diazepines, have been developed to promote sleep. Late last year the National Institutes of Health, Bethesda, held a consensus development conference on "Drugs and insomnia: the use of medications to promote sleep." A much clearer view of the use of hypnotics evolved, and the National Institutes of Health is to be congratulated for providing the opportunity to make this possible.

Consensus conferences are little known outside the United States, but they provide a useful way of updating knowledge. On this occasion after a day and a half of invited presentations a panel of psychiatrists, pharmacologists, epidemiologists, general practitioners, and representatives of the public prepared a statement which dealt with the circumstances in which hypnotics should be used, the pharmacological properties which should be considered, and the principal cautions and risks associated with prescribing these drugs.

Insomnia is a symptom of various conditions and indicates the need for systematic assessment of the medical, psychiatric, and other causes. Analysis of insomnia is best done under three headings-transient, short term, and long term (chronic).

Transient insomnia occurs in those who normally sleep well and is usually due to an alteration in the conditions which surround sleep (for example, noise) or to an unusual pattern of rest, as in shiftwork or intercontinental travel. A hypnotic may or may not be needed, depending on whether the patient reacts unfavourably to unfamiliar surroundings, but when treatment is given a rapidly eliminated hypnotic is appropriate, and it should be needed on only a couple of occasions.

Short term insomnia is usually related to an emotional problem or to a serious medical illness. It may last for a few weeks and may recur. Good management is needed to avoid long term problems, and proper attention to sleep hygiene is essential. A hypnotic is likely to be useful, but it should be given for not more than three weeks-preferably for only a week or so. Intermittent use is desirable, with skipping of some nightly doses after the first few nights of good sleep. A rapidly eliminated drug is usually appropriate to avoid impaired daytime alertness, though for those with any substantial anxiety a slowly eliminated drug may be preferredbut care must be taken to avoid undue sedation related to the accumulation of the drug.

There was considerable controversy over the use of hyp- notics in chronic insomnia. Careful diagnosis is essential before a decision is made. Possibly one third to one half of all such patients have an underlying psychiatric disorder, especially depression, and these patients may need specific treatment. Another group includes those with chronic abuse of drugs or alcohol, and yet others may have specific sleep disorders. From a practical point of view the most important, particularly in the elderly, is sleep apnoea, and in such patients -mainly obese men with a history of snoring or daytime sleepiness or both-sedatives are currently considered to be contraindicated.

Nevertheless, in many patients with chronic insomnia no apparent cause can be established. In these the combined approach of improved sleep hygiene and drug treatment will be needed. The essentials are exercise, controlled curtailment of sleep, and reduction in stress, together with restriction of caffeine and alcohol and the intermittent use of a hypnotic for one night in three for up to a month. In these patients the longer acting benzodiazepines may be more appropriate. If after about a month such treatment is unsuccessful a trial of a sedative antidepressant for, say, a further four weeks was recommended-even in the abser ze of clear cut evidence of depression. This approach needs careful consideration, however, and at the moment may not be widely accepted.

The diazepines are to be preferred to the barbiturates not only because of their safety but also because of their therapeutic usefulness. The main problems which may arise from their use are residual daytime effects (which may be avoided by appropriate dosage of rapidly eliminated compounds); rebound insomnia on withdrawal (which may be avoided by using appropriate doses for short periods and a gradual reduction of dose at the end of the treatment period); dependence (which may be minimised by low intermittent dosage, short duration of administration, and gradual withdrawal if continuous treatment has been given for more than a month); and potentiation by other sedative substances. To avoid these the panel emphasised that patients should always receive the smallest possible dose for the shortest clinically necessary time and that the physician should educate patients in the desirability of the occasional use of low doses and monitor their progress carefully to achieve the desired result.

In all, the recommendations of the panel provide a sensible approach. Treatment with hypnotics along the lines suggested would reduce considerably the problem of the overlong use of sedatives. Furthermore, drug dosage is often unnecessarily high-though with the current emphasis on low doses this is becoming less of a problem. Unneccssarily high doses are used for several reasons: dosage for transient and short term insomnia may be based on inappropriate studies on patients with chronic insomnia, and the requirements of regulatory authorities often demand unequivocal evidence in groups of individuals-again often in patients with chronic insomnia- of a hypnotic effect. The guidelines of the regulatory authorities have a worldwide influence on the subsequent use of these drugs, and they need reappraisal to bring them into line with current medical thought.

JOHN MARKS

Fellow, Tutor, and Codirector of Medical Studies,

Girton College,

Cambridge CB3 0JG

ANTHONY N NichOLSON

Consultant in Aviation Medicine,

Royal Air Force Institute of Aviation Medicine,

Farnborough,

Hampshire GU14 6SZ 